\title{
An Investigation of the Relationship Between Selected Hotel Characteristics and Performance in the Extended Stay Hotel Segment
}

\author{
Zhenxing (Eddie) Mao, Qinglin Mi \\ California State Polytechnic University, Pomona, USA
}

\begin{abstract}
As extended stay hotels gain in popularity across the US, it is important to understand how certain hotel factors influence their performance. The purpose of this paper is to analyze the relationship between selected hotel characteristics (location, scale, size, and operation arrangement) and its performance (revenue per available room (RevPAR)) in the US extended stay market. A multiple regression model is performed on a national dataset, which is available from Smith Travel Research (STR). The findings show that hotels located in urban areas perform the best among all location categories. Upper-tier hotels are able to achieve better results than their lower-tier counterparts. In addition, larger hotels are associated with better performance. Lastly, hotels are advised to adopt the franchise approach as the operation arrangement to achieve higher performance.
\end{abstract}

Keywords: extended stay hotel, hotel property characteristics, hotel performance

\section{Introduction}

The extended stay hotel segment emerged in the US during the 1970s (American Hotel \& Lodging Association, 2012). It usually provides suite-styled accommodations with kitchens, cooking appliances, spacious living rooms, complimentary breakfast, and Wi-Fi. The intention of this segment is to offer more home-like amenities and better value (compared with traditional hotels) to relatively long-term guests so that they would regard the hotel as their home away from home. While welcoming all types of travelers, extended stay properties focus particularly on attracting long-stay guests with a typical 4-7 nights and weekly quote rate (Mayock, 2011; Smith Travel Research [STR], 2012).

The extended stay market witnessed a quick growth since the mid-1990s when major hotel companies started to enter this market (Withiam, 1997). For example, InterContinental Hotels Group (IHG) launched its first Staybridge Suites for long-stay travelers in Alpharetta, Georgia in 1997 (IHG, 2013). In the same year, TownePlace Suites, an all-suite, extended-stay hotel brand in the moderate price range, was launched by Marriott (Stadd, 2013). In fact, 30,339 extended stay hotel rooms were under construction in 1998, accounting for $25 \%$ of the total room construction in the lodging industry for that year (Singh \& Schmidgall, 2000). The supply of extended stay hotels still increased even during the economic recession of 2008 and 2009. In total, 26,160 and

Zhenxing (Eddie) Mao, Ph.D., associate professor, The Collins College of Hospitality Management, California State Polytechnic University. Email: zmao@csupomona.edu.

Qinglin Mi, M.S., The Collins College of Hospitality Management, California State Polytechnic University. 
11,456 extended stay rooms were added to the US hotel supply in 2008 and 2009, respectively (Skinner, 2013). By the end of 2012, this segment represented more than $6 \%$ of the US hotel room supply, which means that there were over 300,000 extended stay rooms in the US (Market Research, 2013). With the development for decades, the extended stay hotel segment is now a stabilized and well-established model (Geieregger, 2008). Although the guest demand for extended stay hotels has continued to grow over the past two decades (Skinner, 2013), the extended stay segment has also faced performance challenges. For instance, the brand "Extended Stay America" filed an unexpected bankruptcy protection in 2009 (Fishman, 2010). Thus, the maturity of the extended stay market segment has created an interest in learning more about why an extended stay hotel property may succeed or fail.

This study attempts to understand how a hotel's characteristics may affect its property performance. Specifically, the purpose of the study is to investigate the relationship between selected hotel characteristics and performance in the extended stay market in the US during the period of 2010-2012. The average US hotel stabilizes in 3.08 years, whereas specifically in the extended stay market, the average hotel stabilization period is only 2.75 years (O'Neill, 2011). Thus, the 3-year average of 2010-2012 is a sufficient period to measure hotel performance. In addition, this 3-year period witnessed a steady economic growth. After the US economic crisis in 2009, the economy began to recover in the year 2010, with a Gross Domestic Product (GDP) growth of 2.5\%. Year 2011 was a year of slow growth for the US economy (Riley, 2011). In 2012, the US GDP grew by $2.8 \%$ after a $1.8 \%$ increase in 2011 (Woodruff \& Wang, 2013). This economic stage showed an uprising trend. The selected hotel features consist of size (i.e., number of rooms), scale (i.e., categories estimated by average daily rate (ADR)), operation arrangement (i.e., independent, franchise, and management contract), and location (i.e., geographic information as urban, suburban, small metro/town, interstate, airport, and resort). The management team usually does not influence these characteristics, and these property traits are difficult to change in the short run.

To the best of our knowledge, this is the first attempt to examine the relationship between a property's characteristics and its performance in the extended stay hotel market using a national sample. The findings may shed some light on how to enhance property performance in the hotel industry. In addition, hotel investors can utilize the findings to make wiser and more knowledgeable investment decisions by searching for good-value properties. Existing hotels can also use the findings to optimize their performance.

\section{Review of Literature}

Previous studies have identified that certain hotel characteristics such as size, location, scale, and operation management could significantly affect its performance. The definition, classification, and examples of each selected hotel characteristic are presented first, followed by the theoretical framework related to property performance. Empirical evidence of the relationship between the characteristics and property performance is reviewed at the end, respectively.

\section{Size}

The size of a hotel is measured by the number of available rooms in the property. Size is one of the primary factors influencing the company's returns on performance (Breen \& Lerner, 1973). Fixed costs, such as plant, property, equipment, and overhead, can be spread across the entire production. In addition, properties can escalate their productivity due to the specialized professional division. Thus, an increase in size will lead to 
reductions in marginal and average costs, a well-defined economic phenomenon called the economies of scale (Economies of Scale, 2014). Consequently, larger organizations may have the benefits of decreased costs based on the size or scope of the operation (Cullen, 1997). Hotels can take advantage of the cost saving and productivity improvement with an increase in room numbers. Therefore, a positive relationship is expected between a hotel's size and its performance.

In the hotel industry, many studies have found a positive relationship between firm size and performance (Barros \& Mascarenhas, 2005; Israeli, 2002). Moreover, medium- or large-sized hotels appear to achieve better performance (Claver-Cortés, Molina-Azorín, \& Pereira-Moliner, 2007). Brown and Dev (1999) analyzed the productivity consequences of hotel strategies. The findings reveal that large hotels produce higher sales revenues and net profits than do the small and medium properties. However, another study has found that the number of rooms is negatively correlated with the revenue per available room (RevPAR), as indicated by the results of Sainaghi (2011), who used individual hotels from Milan. He argued that smaller hotels are able to achieve a higher RevPAR. Empirical evidence has demonstrated an inclusive relationship between hotel size and performance.

\section{Location}

The location choice is of critical importance for hotel properties, because guests must use the rooms and services in that same location. In the lodging industry, STR classifies location into the following six categories: urban, suburban, small metro/town, interstate, airport, and resort. Some properties might reasonably be classified into more than one location category; however, they are typically defaulted to the category that most closely reflects market conditions (Lomanno, 2006).

The location theory is associated with the geographic location of economic activities; it has become an integral part of the economic geography, regional science, and spatial economics (Location Theory, 2014). This theory indicates that savings from a lower transportation fare can cover the higher cost of real estate in a good location. The theory addresses questions of which economic activities are located where and why (Sasaki \& Box, 2003). Firms may choose locations that maximize their profits, and individuals choose locations that maximize their personal utility. In Newell and Seabrook's (2006) study, property location is identified as the second most important factor to influence hotel investment, immediately behind the financial factor.

Lomanno (2006) conducted research for hotel performance by location categories with data from STR in 2005 and 2006. Despite the hotels near interstate and small metro areas achieving a high occupancy rate, the low room rate, which caters to the most cost-conscious guests, led to the worst performance in terms of the RevPAR. Resort hotels have an average RevPAR performance, because the increasing accommodation alternatives such as cruise ships and condo hotels have decentralized the demand. The hotels in airport, urban, and suburban areas outperform the resort, metro, and interstate categories. The outcome confirms that the properties in those locations attracting the most demand for business travelers always perform very well. The findings on the relationship between hotel performance and different locations are inclusive with limited empirical studies.

Scale

The concept of scale, also known as tier, defines hotel segments according to the actual, system-wide average room rates of the major chains (Elder, 2013). STR used the following six hotel brand scales, based on the 2012 Global ADRs: luxury (such as Ritz Carlton), upper upscale (such as Westin), upscale (such as 
Doubletree), upper midscale (such as Holiday Inn), midscale (such as Howard Johnson), and economy (such as Days Inn). The extended stay hotel segment, on the other hand, has only two categories by STR: upper tier (e.g., Hyatt house, Residence Inn, and Homewood Suites) and lower tier (e.g., Candlewood Suites, TownePlace Suites, and Extended Stay of America).

The hotel performance is determined by the trade-off between the ADR and the occupancy percentage. The concept of price elasticity of demand is a measure of the change in demand in response to a price change. If the price is changed and the demand is changed more, the product is said to be elastic. By contrast, a product is inelastic if the price is greatly changed and accompanied by a not-so-large change in demand. Hotel products (room accommodation, food and beverages, etc.) are similar in nature. Their price sensitivity is typically high, which often causes the so-called price wars in the hotel industry. However, some luxury hotels may be able to raise the price without losing much demand, which may lead to better overall performance (Fontinelle, 2010). Therefore, hotels must approach the optimal balance between ADR and occupancy.

Tran (2011) conducted research on the price sensitivity of customers in the luxury hotel segment in the US. The findings indicate that the luxury hotel management is able to change prices with little or no decrease in the occupancy level because of the price inelasticity of the targeted customers' demand. Luxury hotels generate a higher RevPAR. The aggregated dataset for the performance of US branded hotels by segment from 1988 to 2000 within the top 25 markets shows that the luxury sector outperforms other hotel categories (Enz, Canina, \& Walsh, 2001). During economy upturns, luxury hotels exhibited a greater RevPAR than did upper upscale, upscale, upper midscale, midscale, and economy hotels (Ismail, Dalbor, \& Mills, 2002). Hence, the previous empirical evidence suggests that upper-tier properties are associated with better operating performance.

\section{Operation Arrangement}

A business can be organized in one of several ways. The types of operation arrangement in the hotel industry are independent, franchise, and management contract firms (Helmers, 2010). Independent hotels are the properties owned and operated independently, including all non-branded hotels and select brands, which are membership-based (STR, 2012). The merits for independent hotels are that they typically have the opportunities to present a more customized and personal plan (Ellis \& Harris, 2013). Knight (1984) found that independent business owners are more self-reliant, highly motivated, and independent-minded. However, independent management may not be an ideal operating arrangement for a hotel, because owners put their own assets at risk. If the owners are already involved in troubles with personal debt or if the hotel is involved in an activity for which the owners may be sued, then they must have legal arrangements that will better protect their personal assets.

Another type of operation management is franchise. A franchise agreement is a contract that a franchise owner (franchisor) grants rights to a business owner (franchisee) (Friebe \& Bowler, 2012). During the franchising process, business owners pay a franchise fee or royalties to a parent company (the franchisor) for benefits, which include access to brand names, trademarks, reservation services, preparatory steps of feasibility, site selection, financing, marketing, designing, and planning (Welsh, Desplaces, \& Davis, 2011). Hotel franchising entails the value of a whole package of services, including all of the elements essential to establish the franchisee (hotel owner) as the executive of a hotel with the identical look, quality, and criteria as other hotels managed by the franchisor or other franchisees under a same brand (Friebe \& Bowler, 2012). Examples of franchising brands are America's Best Franchising, Inc. (US), Choice Hotels (Global), Flair Hotels 
(Germany), and Wyndham Worldwide (Global) (STR, 2012). In the US, 70\% of hotels are "branded", and there is a solid and regulated franchise system (Friebe \& Bowler, 2012). Franchise hotels enjoy advantages such as mass purchasing, management consultation, wide advertising, central reservations, and systems designs. However, there are also disadvantages to franchising. It costs more for hotels to prepare legal agreements, and these hotels have the potential to lose their freedom. Because the franchisor seeks to expand the alternative channels of distributions or access to various markets, certain legal or other problems regarding the "exclusive territories” might be generated (Holmes, 2012).

A management contract, the third type of operation management, means that the properties with this operation code are all branded and may be either owned or managed by the chain or both owned and managed by the chain (STR, 2012). This type of operating system is defining the difference between the property owner, who agrees to finance or build the property, and the management company of the hotel, which assumes the operational responsibilities (Johnson, 1999). The management company is assumed to execute sales and marketing strategies to maximize the hotel's short- and long-term profitability. Moreover, it is supposed to produce reliable financial statements and establish proper staffing to maximize client and employee satisfaction (Johnson, 1999). One of these duties is to report periodically to owners about a business condition. However, these owners are not skilled at managing hotels. Hence, they must seek help from professional management companies to operate the property. Owners are able to enjoy certain advantages. The management contract, along with a strong combination of hotel brand and managerial abilities, should improve the hotel's performance (Hayes, 2007). Moreover, a management company requires compliance with terms and criteria for the hotel's furniture, fixtures and equipment, property quality, structure, and building system, all of which contribute to superior performance (Kim, 2008). However, management contract hotels also have disadvantages, such as the owner being unable to control the selection of the on-site general manager and other high-level managers. In fact, sometimes, the concerns of hotel owners and the management companies they employ conflict with each other. Furthermore, the cost of the mistakes caused by the management company or ownership transfer may result in a buyout, limiting the number of potential buyers (Hayes, 2007).

No extended stay hotel is listed as an independent firm in the entire STR database. Therefore, only hotels with operation type for franchise or management contract will be studied and analyzed in the present paper. Previous studies support that management-contracted hotels perform better than franchised or independent hotels (Kim, 2008). Vandyke (1985) found no relationship between the management contract and hotel performance when he attempted to explore the main factors affecting hotel profitability. The mixed findings on the operating management made it difficult to draw a clear conclusion regarding the relationship between the operation arrangement and hotel performance.

\section{RevPAR}

RevPAR is calculated by dividing a hotel's total guestroom revenue by the room count and the number of days in the period measured. It captures the nature of both ADR and occupancy rate, making it a better measurement. Thus, when measuring the profit and sales performance of hotels, the RevPAR should be the focus for analysis (Arnold, 1994; Malk \& Schmidgall, 1993). The RevPAR is the most widely used operating performance metric for hotel productivity and has consistently presented an important barometer of hotel trends (Brown \& Dev, 1999; Gallagher \& Mansour, 2000). The present study uses the RevPAR to measure hotel performance. 


\section{Methodology}

\section{The Proposed Model}

In consideration of the related literature review, the following equation is proposed to explore the relationships among the selected characteristics (size, hotel scale, operation arrangement, and location) as the independent variables and hotel performance as the dependent variable:

$$
H P=\beta_{0}+\beta_{1} S+\beta_{2} H S+\beta_{3} O A+\beta_{4} L+\varepsilon
$$

where:

HP: Hotel performance. The RevPAR is used to measure the hotel operating performance (monthly average);

$S$ : Size (The number of rooms in each hotel);

HS: Hotel scale (Only upper and lower tiers are defined for the extended stay segment in the STR data);

$O A$ : Operation arrangement (Only franchise and management contract types are available for the extended stay hotel in the STR data);

$L$ : Location (Urban, suburban, airport, interstate, small metro/town, and resort categories are used in the STR data. Because those locations are mutually exclusive categories, dummy variables were used to sort data with code $1 \mathrm{~s}$ and $0 \mathrm{~s})$;

$\beta_{0}$ : The intercept;

$\beta_{1}-\beta_{4}$ : The beta coefficient or slope of each independent variable;

$\varepsilon$. The random error term or the residual portion.

\section{Data Collection}

This study includes all available active extended stay hotels throughout the US with monthly data from STR databases. Specifically, STR provides property's RevPAR for 2010, 2011, and 2012. In addition, for each hotel, STR has the data of the extended stay hotel tier, location, number of rooms, and type of operation arrangement. There were a few missing and erroneous data for several hotels in certain months or years. These observations were prescreened and eliminated from the dataset by a listwise deletion to conduct the analysis.

\section{Results}

\section{Descriptive Statistics}

Table 1 presents the descriptive statistics for the continuous variables used in the study. In total, 3,204 sample data were gathered from secondary databases from STR. After deleting 387 missing data and removing seven outliers indicated by Statistical Package for Social Sciences (SPSS), 2,810 samples are being run in this paper. The RevPAR averages $\$ 56.10$, with a minimum of $\$ 12.11$ and a maximum of $\$ 244.89$. The hotel size ranges from 30 to 411 rooms, with a mean of 111.61 rooms. Regarding the data from American Hotel \& Lodging Association from 2010 to 2012, the hotel industry in the US has an average RevPAR at \$60.89 and an average room size at 94 rooms (American Hotel \& Lodging Association, 2012). Within the hotel industry, the extended stay segment is large in size but is slightly lower in RevPAR during the same period. 
Table 1

Descriptive Statistics for the Continuous Variables

\begin{tabular}{llllll}
\hline Continuous variable & $N$ & Minimum & Maximum & Mean & Std. deviation \\
\hline Performance & 2,810 & 12.11 & 244.89 & 56.10 & 26.62 \\
Size & 2,810 & 30 & 411 & 111.61 & 31.32 \\
\hline
\end{tabular}

An analysis to describe the categorical variables is summarized in Table 2. In the sample set, suburban comprised the largest group ( $N=1,920,68.30 \%)$. Airport represented the second largest group $(N=258,9.20 \%)$. Urban $(N=216,7.70 \%)$ was the third largest group. Small metro/town $(N=213,7.60 \%)$ was the fourth. Interstate had 133 (4.70\%) properties, which was the fifth. Resort possessed the least, with 70 (only 2.50\%) properties. The scale variable for the extended stay hotel segment is divided into two categories. The lower tier comprised the largest category $(N=1,619,57.60 \%)$. The remaining hotels belong to the upper tier $(N=1,191,42.40 \%)$. In the operation arrangement category, franchise $(N=1,622,57.70 \%)$ is more frequently applied than the management contract $(N=1,188,42.30 \%)$.

Table 2

Descriptive Statistics for the Categorical Variables

\begin{tabular}{lrr}
\hline Categorical variable & Frequency & Percentage (\%) \\
\hline Hotel location & & 68.30 \\
\hline Suburban & 1,920 & 9.20 \\
Airport & 258 & 7.70 \\
Urban & 216 & 7.60 \\
Small metro/town & 213 & 4.70 \\
Interstate & 133 & 2.50 \\
Resort & 70 & 100.00 \\
Total & 2,810 & \\
Scale & & 57.60 \\
Lower tier & 1,619 & 42.40 \\
Upper tier & 1,191 & 100.00 \\
Total & 2,810 & \\
\hline Operation arrangement & & 42.30 \\
Management contract & 1,188 & 57.70 \\
Franchise & 1,622 & 100.00 \\
Total & 2,810 & \\
\hline
\end{tabular}

\section{Multiple Regressions Statistics}

Prior to performing the multiple regression analysis, several tests for outliers, normality, and linearity were preformed to check the assumptions of the model. No violation was detected. The summary of the multiple regression analysis is presented in Table 3 . The adjusted $R$-square (0.576) indicates that the model has an appropriate goodness of fit for this empirical study, showing that $57.6 \%$ of the variation in the dependent variable can be explained by variations in the independent variables. The variable scale accounts for $53.1 \%$, which is the largest proportion explaining the variance ( $R$-square change $=0.531$ ). The other variables including operation arrangement, location, and size account for the remaining $4.6 \%$ to explain the variance. The $p$-values of all independent variables were less than 0.05 . The highest variance inflation factor (VIF) value is 3.310, which is far below the cut-off value of 10 proposed by Hair, Black, Babin, and Anderson (2009), indicating no concern for multicollinearity. 
The model is statistically significant, and the above variables have significant relationships with extended stay hotel performance. It is evident that in operation management, franchise management outperforms the management contact and has a positive relationship with hotel performance. All else being equal, the hotel can earn a higher RevPAR, specifically, 8.522 dollars more being a franchise management than being a management contract. In the scale sector, upper-tier properties perform better in the extended stay hotel segment. Upper-tier hotels, on average, are able to achieve 34.371 dollars more in the RevPAR, compared with lower-tier hotels. Regarding size, the larger extended stay hotels tended to perform better than did the lower-tier hotels. An additional room in a property will bring an extra 0.084 dollars in hotel performance. In the location category, interstate, suburban, metro, resort, and airport have significant negative coefficients with hotel performance, implying that these locations hinder hotel performance and that urban locations performed the best.

Table 3

Regression Summaries

\begin{tabular}{|c|c|c|c|c|c|c|c|c|}
\hline \multirow[t]{2}{*}{ Model } & \multicolumn{2}{|c|}{$\begin{array}{c}\text { Unstandardized } \\
\text { coefficient }\end{array}$} & \multirow{2}{*}{$\begin{array}{l}\text { Standardized } \\
\text { coefficient } \\
\text { Beta }\end{array}$} & \multirow[t]{2}{*}{$T$} & \multirow[t]{2}{*}{ Sig. } & \multicolumn{2}{|c|}{ Collinearity statistic } & \multirow{2}{*}{$\begin{array}{l}R \text {-square } \\
\text { change }\end{array}$} \\
\hline & B & Std. error & & & & Tolerance & VIF & \\
\hline (Constant) & 39.338 & 2.033 & & 19.348 & 0.000 & & & \\
\hline Scale & 34.371 & 0.747 & 0.638 & 46.002 & 0.000 & 0.783 & 1.277 & 0.531 \\
\hline Size & 0.084 & 0.012 & 0.099 & 7.318 & 0.000 & 0.821 & 1.217 & 0.015 \\
\hline Operation & 8.522 & 0.769 & 0.158 & 11.085 & 0.000 & 0.740 & 1.351 & 0.014 \\
\hline Suburban & -13.544 & 1.278 & -0.237 & -10.597 & 0.000 & 0.302 & 3.310 & 0.006 \\
\hline Metro & -10.904 & 1.743 & -0.108 & -6.254 & 0.000 & 0.501 & 1.994 & 0.004 \\
\hline Interstate & -14.580 & 1.976 & -0.116 & -7.378 & 0.000 & 0.606 & 1.649 & 0.003 \\
\hline Resort & -9.539 & 2.384 & -0.056 & -4.002 & 0.000 & 0.774 & 1.293 & 0.002 \\
\hline Airport & -12.273 & 1.610 & -0.133 & -7.625 & 0.000 & 0.494 & 2.023 & 0.002 \\
\hline
\end{tabular}

Notes. Dependent variable: Performance. Adjusted $R$-square: 0.576.

\section{Conclusions}

This research examines the relationship between selected hotel characteristics (size, scale, operation arrangement, and location) and operating performance in the extended stay hotel segment during the period of 2010-2012. The findings indicate that all these characteristics have significant impacts on the extended stay hotel performance.

First, the results have confirmed a generally linear relationship between hotel size and performance during three years that were studied (from 2010 to 2012), with a positive and significant coefficient of size $(S)$. This finding indicates that hotel performance at the per-room level improves with an increased room inventory, suggesting the benefit of scale economy. The important implication for existing chain operators who have small-sized and middle-sized properties is that they should consider adding additional rooms to expand the size of their prototype hotels and thereby improve their performance in terms of productivity. For some existing independent hotels, it is not easy to change the hotel size in the short term, but it can still be expanded in the long term. On the other hand, it is better for hotel investors to select a large-sized extended stay hotel for investment, which has the potential to achieve better performance during an economic upturn. 
Second, hotel performance is positively correlated with the hotel scale. The regression results showed that the upper-tier extended stay hotels performed much better than did their lower-tier counterparts during the period of 2010-2012. A hotel's performance is largely affected by its scale. The hotel performance highly depends on average daily rate, so it is not wise to use the cut-price strategy doing the competition. It would be advisable for the existing chain hotels, while controlling other features, by raising the average room rate, upgrading their facilities and adding more services to attract more wealthy guests and thereby improve the operating performance. When hotel investors intend to invest in an extended stay property, greater emphasis should be placed on upper-tier hotel categories to achieve a greater earning potential during a booming economy.

Third, it is worth noting that when other effects such as size, hotel scale, and location are controlled, franchise hotels exhibit a much higher RevPAR than management contract hotels do. This is a clear implication that franchises indeed have an efficiency advantage over management contract hotels. New extended stay hotels are advised to choose a franchise relationship instead of contract management. The owner of the franchise hotel requires the services of a third party, namely, the non-branded management company, to manage the day-to-day hotel operations. The superior performance of the franchise may be because the non-branded management company focuses more and specializes in managing the hotel in a strategic manner (Friebe \& Bowler, 2012). Therefore, the existing extended hotel is recommended to transfer the management company to those who focus more on management, which may help to achieve better performance.

Fourth, hotel investors always place strong emphasis on the location attributes (Newell \& Seabrook, 2006). As a note to the present research, the urban location, the wealth of the property type that caters to group and transient business travelers, has prospered most over the other five categories (suburban, interstate, resort, small metro, and airport). This phenomenon might also be due to less supply and excess demand, together with the extremely aggressive pricing strategies through revenue management. The study reveals that, although real estate and facilities cost more in urban areas, the benefits in urban areas such as savings on transportation can arouse a huge demand. Therefore, investors are still encouraged to invest in extended stay hotels in urban areas compared with other location types.

Finally, hotel investors should remember that size, scale, operation arrangement, and location usually work together instead of separately, especially in new hotel development projects and in hotel acquisitions. For existing hotels, adjusting any one of these characteristics will mutually affect the others. Thus, multiple strategies are often utilized concurrently, and a hotel's performance depends on the cumulative results. Accordingly, hotel owners should not rely on one particular strategy while disregarding the possible effects of others.

This paper concentrates only on the extended stay hotel segment with four selected hotel characteristics from 2010 to 2012 in the US. The findings from this study might not be generalizable to the entire hotel industry. Future studies should include additional hotel segments, or even the entire industry, with a longer time frame and more selected hotel characteristics.

\section{References}

American Hotel \& Lodging Association. (2012). The lodging industry's chief trade association. Retrieved from http://www.ahla.com/

Arnold, D. (1994). Profits and prices: A lodging analysis. Cornell Hotel and Restaurant Administration Quarterly, 35(1), 30-33. 
Barros, C. P., \& Mascarenhas, M. J. (2005). Technical and allocative efficiency in a chain of small hotels. International Journal of Hospitality Management, 24(3), 415-436.

Breen, W., \& Lerner, E. (1973). Employee selection methods. Management. Retrieved from http://best-management-articles.blogspot.com/2013/05/employee-selection-methods.html

Brown, J. R., \& Dev, C. S. (1999). Looking beyond RevPAR: Productivity consequences of hotel strategies. Cornell Hotel and Restaurant Administration Quarterly, 40(2), 23-33.

Claver-Cortés, E., Molina-Azorín, J. F., \& Pereira-Moliner, J. (2007). The impact of strategic behaviours on hotel performance. International Journal of Contemporary Hospitality Management, 19(1), 6-20.

Cullen, P. (1997). Economics for hospitality management. Oxford: International Thomson Business Press.

Economies of Scale. (2014). In Business Dictionary Online. Retrieved from http://www.businessdictionary.com/definition/economies-of-scale.html

Elder, C. (2013). An overview of hotel asset classes. U.S. Hotel Appraisals. Retrieved from http://www.ushotelappraisals.com/services/hotel-asset-classes-limited-service-hotels/

Ellis, J., \& Harris, B. (2013). What is an independent business? Retrieved from http://www.wisegeek.com/what-is-an-independent-business.htm

Enz, C. A., Canina, L., \& Walsh, K. (2001). Hotel-industry averages: An inaccurate tool for measuring performance. Cornell Hotel and Restaurant Administration Quarterly, 42(6), 22-32.

Fishman, L. (2010, October 14). Extended stay Inc. emerges from bankruptcy after \$3.93 billion sale. Phoenix Bankruptcy News. Retrieved from http://phoenixbankruptcynews.com/2010/10/extended-stay-inc-emerges-from-bankruptcy-after-393-billion-sale.html

Fontinelle, A. (2010). Starting a small business. Retrieved from http://www.investopedia.com/

Friebe, K., \& Bowler, I. (2012). Hotel franchising in Europe. Retrieved from http://www.dlapiper.com/en/global/

Gallagher, M., \& Mansour, A. (2000). An analysis of hotel real estate market dynamics. Journal of Real Estate Research, 19(2), 133-165.

Geieregger, E. (2008). A home for the modern nomad: Extended stay hotels. Journal of Retail and Leisure Property, 7(3), 216-233.

Hair, J. F., Black, W. C., Babin, B. J., \& Anderson, R. E. (2009). Multivariate data analysis (7th ed.). Upper Saddle River, N.J.: Prentice Hall.

Hayes, N. (2007). Hotel operations management (2nd ed.). Upper Saddle River, N.J.: Prentice Hall.

Helmers, C. G. (2010). The importance of ownership form and spatial location in the lodging industry: An empirical analysis of the hotel sector in Texas. Ann Arbor, M.I.: ProQuest, UMI Dissertation Publishing.

Holmes, D. E. (2012). The advantages and disadvantages of franchising. Retrieved from http://www.studymode.com/essays/The-Advantages-And-Disadvantages-Of-Franchising-1331775.html

InterContinental Hotels Group [IHG]. (2013). About us-Our history. Retrieved from http://www.ihgplc.com/

Ismail, J. A., Dalbor, M. C., \& Mills, J. E. (2002). Using RevPAR to analyze lodging-segment variability. Cornell Hotel and Restaurant Administration Quarterly, 43(6), 73-81.

Israeli, A. A. (2002). Start rating and corporate affiliation: Their influence on room price and performance of hotels in Israel. International Journal of Hospitality Management, 21(4), 405-424.

Johnson, K. (1999). Hotel management contract terms: Still in flux. Cornell Hotel and Restaurant Administration Quarterly, 40(2), 34-39.

Kim, S. Y. (2008). Hotel management contract: Impact on performance in the Korean hotel sector. Service Industries Journal, 28(5), 701-718.

Knight, R. M. (1984). The independence of the franchiser entrepreneur. Journal of Small Business Management, 22(2), 53-61.

Location Theory. (2014). In Wikipedia Online. Retrieved from http://en.wikipedia.org/wiki/Location_theory

Lomanno, M. (2006). Location can change outlook for performance picture. Trends \& Stats. Retrieved from http://www.HotelMotel.com/digital_edition

Malk, M., \& Schmidgall, R. (1993). Financial analysis of the rooms department. The Bottom Line, 8(6), 18-22.

Market Research. (2013). The 2013-2014 travel \& tourism market research handbook. Retrieved from http://www.marketresearch.com/Richard-K-Miller-Associates-v723/Travel-Tourism-Research-Handbook-7358307/

Mayock, P. (2011). STR: Niche segment performance overview. Retrieved from http://www.hotelnewsnow.com/Article/6178 
Newell, G., \& Seabrook, R. (2006). Factors influencing hotel investment decision making. Journal of Property Investment and Finance, 24(4), 279-294.

O’Neill, J. W. (2011). Hotel occupancy: Is the three-year stabilization assumption justified? Cornell Hospitality Quarterly, 52(2), 176-180.

Riley, G. (2011). 2011 in review-The US economy. Tutor2u Resources \& Events Store. Retrieved from http://www.tutor2u.net/blog/index.php/economics/comments/2011-in-review-the-us-economy

Sainaghi, R. (2011). RevPAR determinants of individual hotels evidences from Milan. International Journal of Contemporary Hospitality Management, 23(3), 297-311.

Sasaki, Y., \& Box, P. (2003). Agent-based verification of von Thünen's location theory. Journal of Artificial Societies and Social Simulation, 6(2). Retrieved from http://jasss.soc.surrey.ac.uk/6/2/9.html

Singh, A. J., \& Schmidgall, R. S. (2000). Financing lodging properties. Cornell Hotel and Restaurant Administration Quarterly, 41(4), 42-51.

Skinner, M. (2013). Extended-stay hotels draw demand, investment. Retrieved from http://www.hotelnewsnow.com/Article/10171/Extended-stay-hotels-draw-demand-investment

Smith Travel Research [STR]. (2012). Terminology definitions. Retrieved from http://www.strglobal.com/Media/Default/Documents/Definitions.pdf

Stadd, J. (2013). TownePlace suites ranked \#1 extended-stay brand by J.D. Power. Retrieved from http://news.marriott.com/2013/07/towneplace-suites-ranked-1-extended-stay-brand-by-jd-power-.html

Tran, X. (2011). Price sensitivity of customers in luxurious hotels in U.S.. e-Review of Tourism Research, 9(4), 122-133.

Vandyke, T. (1985). An exploratory study of key variables affecting profitability in the lodging industry (hotels, motels, restaurant, regressions). N.P.: ProQuest, UMI Dissertations Publishing.

Welsh, D. H. B., Desplaces, D. E., \& Davis, A. E. (2011). A comparison of retail franchises, independent businesses, and purchased existing independent business startups: Lessons from the Kauffman firm survey. Journal of Marketing Channels, 18(1), 3-18.

Withiam, G. (1997). Extended stay: Hot, hot, hot. Cornell Hotel and Restaurant Administration Quarterly, 38(1), 12-25.

Woodruff, C., \& Wang, C. (2013). Widespread economic growth in 2012. Retrieved from http://www.bea.gov/newsreleases/regional/gdp_state/2013/pdf/gsp0613.pdf 